\title{
INFORMATION FLOW REGARDING INVOICES AND OUTSTANDING BENEFICIARIES IN AN "ACCESS" APPLICATION
}

\author{
Daniel Daneci-Patrau*, Andreea Jenaru \\ Spiru Haret University, Constanta, Romania \\ Maritime University, Constanta, Romania \\ *Corresponding author: Daniel Daneci-Patrau, daniel.daneci@spiruharet.com
}

Received: 12. 18. 2020

Accepted: 02. 04. 2021

\begin{abstract}
The importance and actuality of the theme are yielded by the increase in the complexity of actions undergone by the economic agents in the context of the development and diversification information instruments aimed at observing the invoice collection pattern and the calculation of work productivity used to manage economic, social and institutional variables in view of fulfilling the organizational objectives. All these evolutions force to re-imagine the strategic role of the information softwares at the organizational level. Together with the human resource they are considered the main competitive advantage modern organizations benefit from. This work consists of the methodology and sequential algorithm to create an information app which can be used to track outstanding invoices by any economic agent. The conclusions drawn from this work emphasize the importance of a proper use of the designed app in the tracking and collection activity in regard to outstanding invoices, generating improvements of the financial flows and turnover increase.
\end{abstract}

Keywords: data base, decision, information system management, overdue invoices.

Rezumat. Importanța și actualitatea temei sunt cauzate de creșterea nivelului de complexitate a acțiunilor întreprinse de agenții economici în contextul utilizării instrumentelor de informare, dezvoltare și diversificare în ceea ce vizează respectarea tiparului de colectare a facturilor și a calculului productivității muncii. Utilizate pentru gestionarea economică în vederea îndeplinirii obiectivelor organizaționale, aceste variabile sociale și instituționale impun un rol strategic softurilor informaționale la nivel organizațional. Împreună cu resursa umană, acestea sunt considerate principalul avantaj competitiv de care beneficiază organizațiile moderne. Această lucrare abordează metodologia și algoritmii secvențiali pentru a crea o aplicație de informații care poate fi utilizată pentru a urmări facturile restante de către orice agent economic. Concluziile lucrării subliniază importanța utilizării corespunzătoare a aplicației proiectate în activitatea de urmărire și colectare a facturilor restante, generând îmbunătățiri ale fluxurilor financiare și creșterea cifrei de afaceri.

Cuvinte cheie: bază de date, decizie, gestionarea sistemului informațional, facturi restante.

\section{Introduction}

In the context of present society characterised by an unprecedented information explosion in the history of mankind, the information systems represent one of the fundamental elements, which generate and control the information flows at micro and macroeconomic level. 
The theoretical substantiation and the practical examples necessary for the development and use of some database applications, which integrate a lot of new information technologies, impose that the developer or the user of some evolved database systems already know the fundamental aspects of this field: databases, database management systems, relational systems, programming languages, programming techniques. If the expert systems were developed at the beginning in the technical and medical field, we recently witness their extension in the economic field and especially in the financial-banking field [1].

All applications of management information system use the structured information one way or another. Microsoft Visual Basic integrated in Microsoft Access provides us all the necessary instruments for the creation and use of the structured database systems for the management of our own data applications. The logical procedure or the functional unit is the correspondent of the subtask within an application from the computer field. Only at this level the direct transfer from the logical structure of the application to programs can be easily done, which means that a functional unit can be associated with one or more processing units or automatic procedures from the application software. The last situation is necessary especially when also within a processing unit there are more elements of organisational structure involved. In agreement with the opinion of a specialised literature author, I consider that the data represent a crucial organisational resource and have to be managed similar to the management of the important assets of an enterprise [2]. Without data on the internal functioning and on the external environment, the enterprises could not survive or succeed in business. Their volume is unceasingly growing. Their organising and memorising on addressable technical supports (HD, FD, CD-ROM, removable disc) are a lot facilitated by the fact that, we operate mostly with data structures. Another solution, dominant at present, consists in organising data in databases, defined as a structured set of data registered on supports accessible to the computer in order to simultaneously satisfy more users in a selective manner and in time [3]. Furthermore, this structured set of data contains data structures functionally linked. Databases are unitarily managed through dedicated programs, called database management systems (DBMS).

The database is described independently from the programs that use the data. The description aims at the same time the data structures, the links between them and the rules that assure the data coherence.

The information system objectives at macro level are [4]:

- Supporting the information process, respectively assuring the support for collecting, filtering and conveying the data that characterise the company's activity;

- Supporting the decision-making process, which refers to providing the necessary information for taking decisions in semi-structured or unstructured problems;

A definition closer to the study of information systems considers the system as a set of interrelated components that track a common objective in the process organised to transform the resources into outputs [5]. The study and the research of processes and of economic-social phenomena, characterised through complexity and dynamism, impose the use of system theory, whose object is represented by the research of the surrounding world seen as a set made of subassemblies that strongly interact with each other. The purpose of this research is to identify causal links between economic phenomena and processes in order to substantiate decisions [6].

\section{Application design methodology}

Within the current evolution of the economy and society the necessity of the existence of a computer system designed for data organising, for extracting information useful in decision making is needed [7]. Taking into consideration the specialists' position and taking into account the specifics of the activity currently performed, in this chapter we built an excellent computer 
system, where the data are presented directly, quickly, synthetically and which allows the executive manager to see and analyse the situation of the outstanding invoices of the enterprise.

Computers and data communication technology alters the parameters for the development of competition in all activity fields. If information technology used to be focused in data storage, nowadays it has to provide a dynamic vision on the organization, facilitating company's adjustment to environment changes and providing its competitiveness. In this way, information technology becomes an extremely efficient competition weapon in achieving the organization's tasks [8].

\section{Computer application design}

Outstanding invoices tracking application was created using Microsoft Office Access environment. Application tables are: Beneficiary, Invoices, Invoice details, Delegate, Materials, Categories.

Conceptual data modeling for achieving application is shown in Figure 1.

The relational model of data is as follows:

BENEFICIARY(Beneficiary_code,Name_beneficary,Fiscale_code,Bank, Bank_account).

INVOICE (Number, Serie1, Serie2, Invoice_date, Payment_term, Cashing_date, Payment_mode, Number wo accompanying the goods, vat, Beneficiary_code, Name_beneficary, address, city, state, Bank_account, bank, Fiscale_code, Delegates from company, delegate Out, Delegate_code, Delegate_name, ID, Transport_Number, Date_shipping, Time_shipping, State document, total payment, comments, date, delegat_semn_checked, ex2_orig_checked, ex2_semn_checked, stamp_checked, record_store_checked.

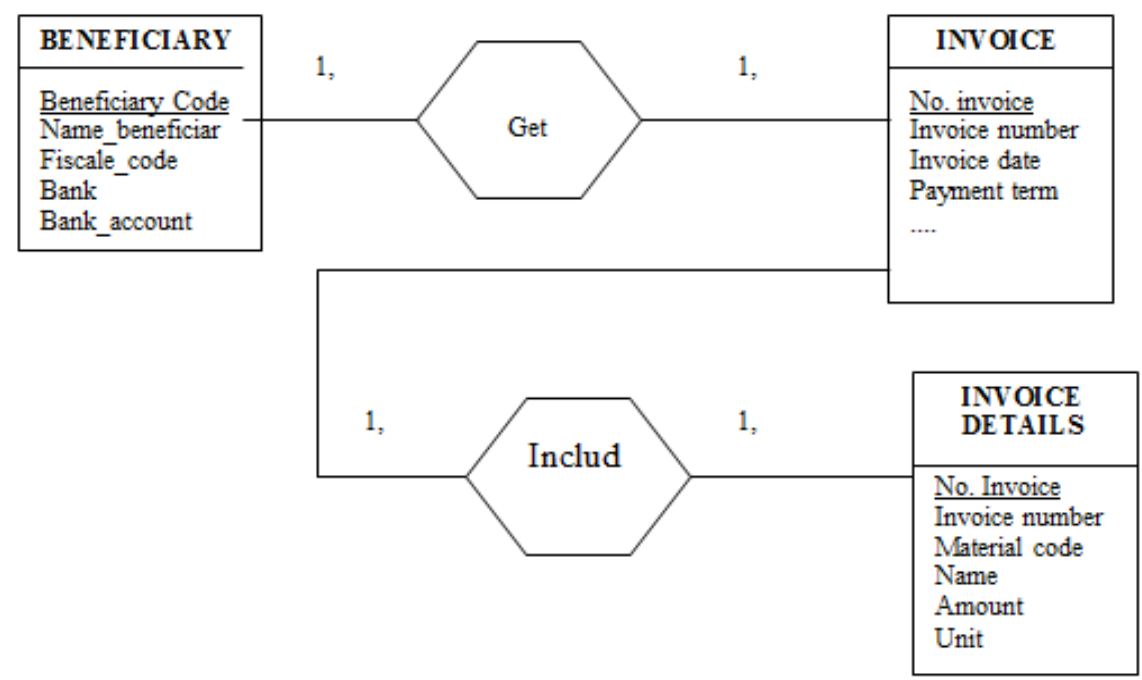

Figure 1. Conceptual data modeling.

INVOICE DETAILS (Invoice_number, Material_code, Name, Amount, Unit, Quantity, Product_price).

CATEGORIES (Category_code, Category, Coefficient_added).

MATERIALS (Material_code, Name, Details, Measurement_units, Category, Price, Warehouse_role, last inputs, currency, currency warehouse unit price, unit price recombinant currency).

Corresponding tables relational model are shown in Figure 2. 


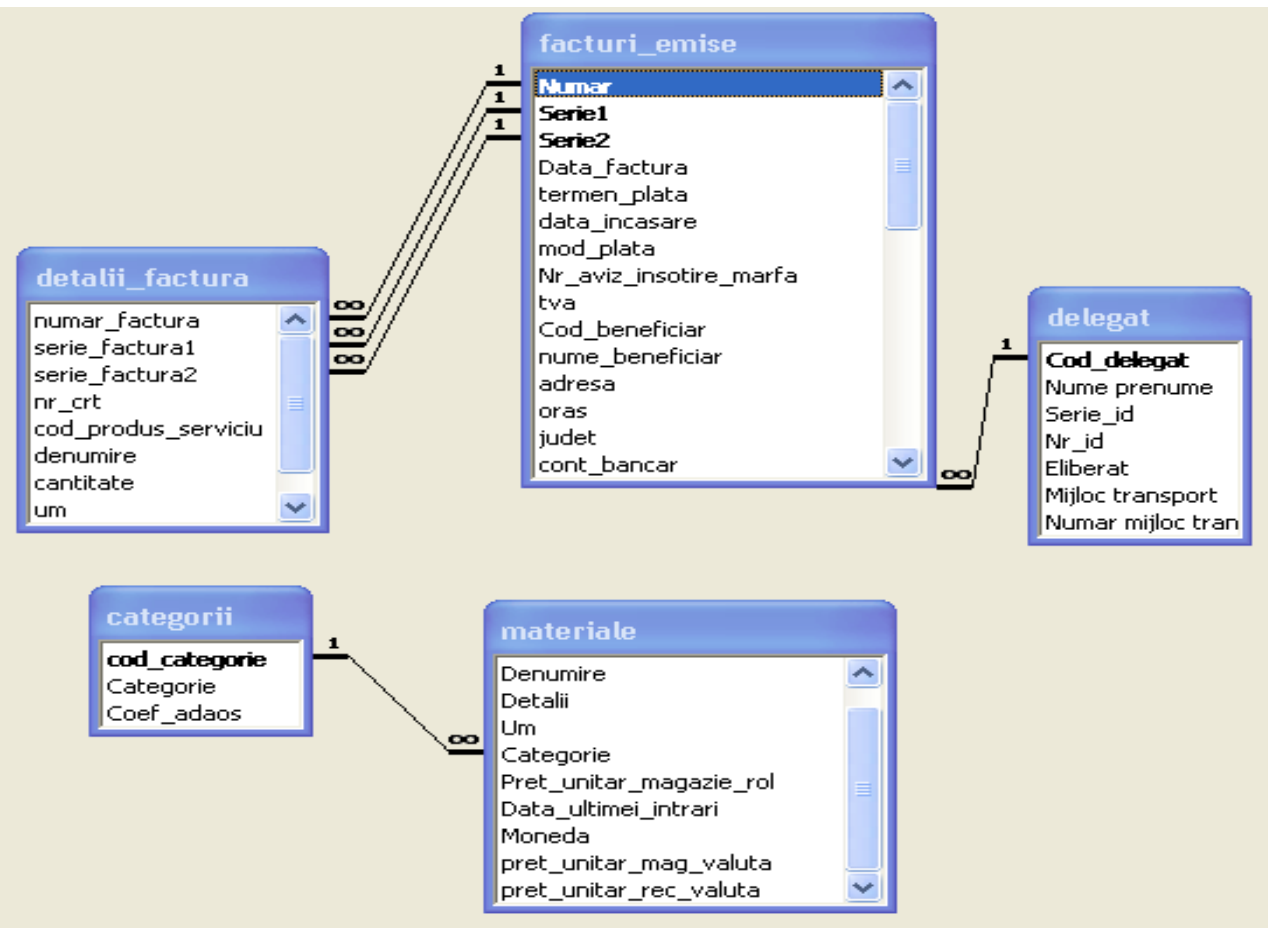

Figure 2. Relationships between database tables created.

Main interface shown in Figure 3, allows access to important database options namely: Add invoices, bills Change, Introduction exchange rate (option Dollar / Euro) output statements (statements), Letters to debtors beneficiaries (recipients addresses).

Box form designed to introduce foreign exchange necessary in pursuing outstanding bills.

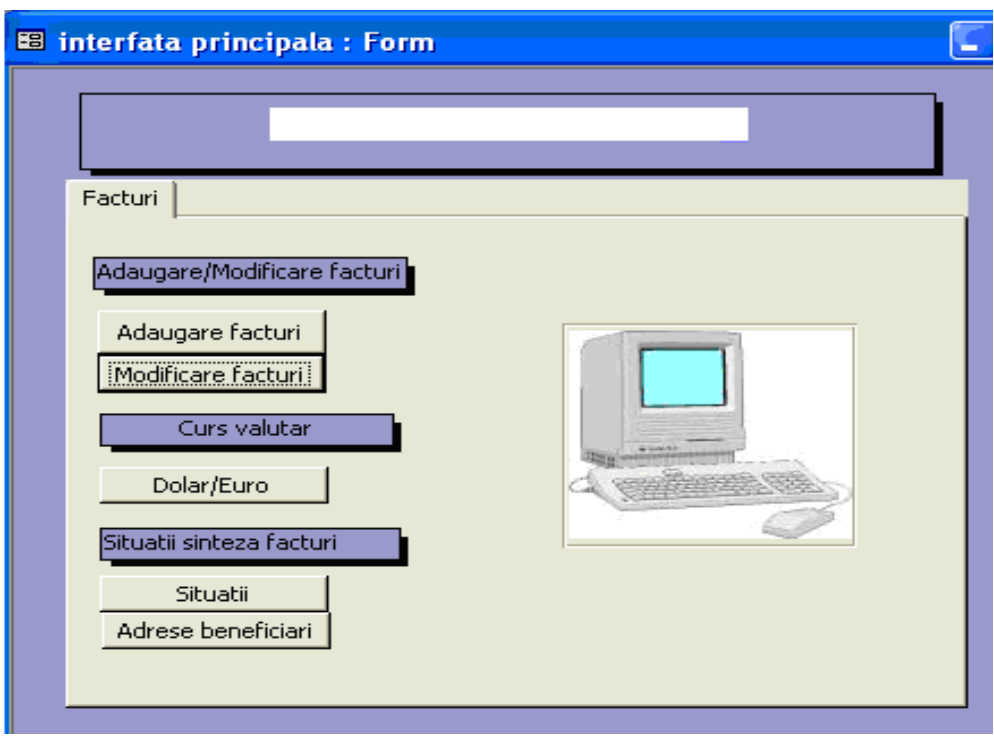

\section{Invoices form creation}

Figure 3. The main interface.

Invoice form is a form that contains a subform complex, combobox box, text boxes, buttons action. We describe all items invoice form. In Figure 4 is shown the section relating to beneficiary selection. Recipient is selected using a combobox type application. After selecting the beneficiary will complete all the fields that are located under selection box buyer. 


$\begin{array}{lll} & \text { Serie } & \text { Numar } \\ \text { Selectie cumparator } & \text { Petroconst SA } \\ \text { Nume cumparator } & & \\ \text { Nr inregistrare fiscala } & \text { R6162290 } \\ \text { Registrul Comertului } & \text { J13/3113/1994 } \\ \text { Sediu } & \text { IC Bratianu 45 } \\ \text { Oras } & \text { Constanta } \\ \text { Judet } & \text { Constanta } \\ \text { Cont } & \text { SV06349861400 } \\ \text { Banca } & \text { BRD } \\ & \text { Actualizare modificari } & \text { Sterge inregistrare } \\ & 4 . \text { Selection box On purchaser. }\end{array}$

Figure 4. Selection box on purchaser.

Event combo box is attached tape after-update and reads:

Private Sub Cod_beneficiar_AfterUpdate()

Dim rc As Recordset

Dim baza As Database

Set baza $=$ CurrentDb()

Set $r c=$ baza.OpenRecordset("query1", dbOpenDynaset)

If IsNull(Me!Cod_beneficiar) Then

GoTo sfarsit

End If

rc.FindFirst "cod_beneficiar=" \& Me!Cod_beneficiar

If $\mathrm{rc}$. NoMatch $=$ True Then

MsgBox "Eroare de cautare. Beneficiar negasit"

GoTo sfarsit

End If

Me!NUME_BENEFICIAR $=$ rc!NUME_BENEFICIAR

Me!adresa $=$ rc! adresa

Me!oras $=$ rc!oras

Me!judet $=$ rc!judet

Me!cont_bancar =rc!cont_bancar

Me!banca $=$ rc! banca

Me!registrul_comertului =rc!registrul_comertului

Me!cod_fiscal =rc!cod_fiscal

sfarsit:

rc.Close

End Sub

Another important element of the form is subform invoice containing materials, the effect of the action, as shown in Table 1.

Table 1

Subform record a bill of materials remaining

\begin{tabular}{|r|r|r|r|r|r|r|r|r|}
\hline & Nr_crt & Cod_produs_servi & Denumire & Uhi & Cantitat & Pret_prod & Valoarea & Valoare \\
\hline & 1 & $005 \mathrm{E} 91360$ & Imprimanta HP 1010 & BUC & 2 & 475.00 & 950.00 & 228.00 \\
\hline & & & & & 0 & 0.00 & 0.00 & 0.00 \\
\hline
\end{tabular}

Subform has fields calculated as follows: 


$$
\begin{gathered}
\text { Value }=\text { Price * Quantity } \\
\text { Value product VAT }=24 \% * \text { Value }
\end{gathered}
$$

Product code is selected from a list of all available codes. Once the code is complete and the product name and price. Product code field is a combo box and is attached to an event trigger after update after that will use the following code:

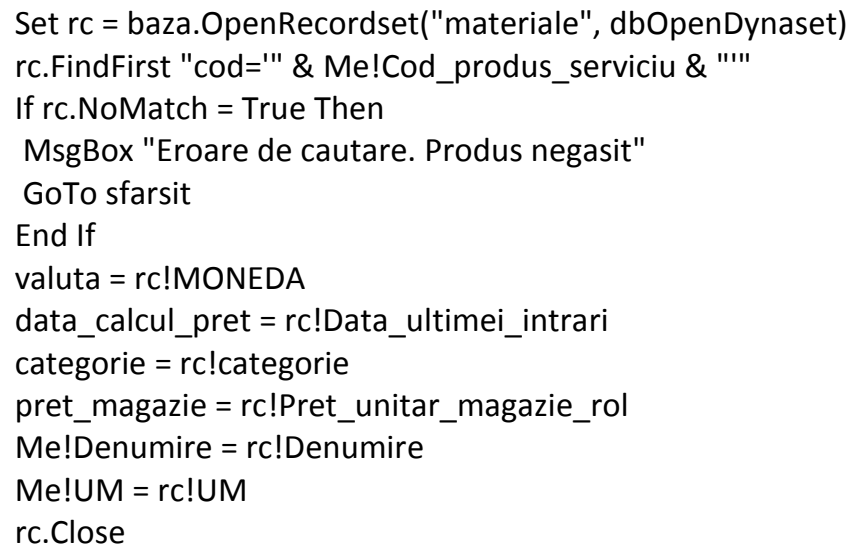

\section{Module for situations with outstanding invoices}

Circumstances module consists of several forms, namely: List_invoices, summary_statements, invoices_search. We describe the List_invoices form, shown in Figure no. 5.

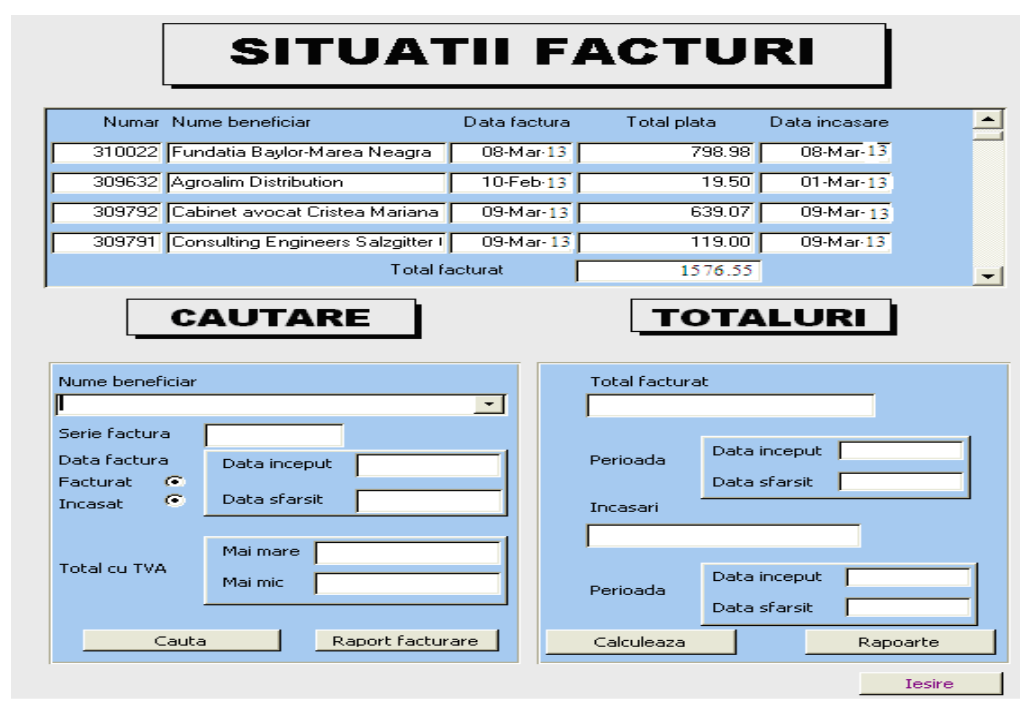

Figure 5. Form List invoices.

Upper half of the form contains selected invoices by a certain criterion that can be billed on the date of invoice receipt, the invoice recipient. In the bottom half of the form are search options and obtaining totals. For invoices selection criteria can be used options customer name, invoice number, invoice date, invoice and charged options. Once this option is actuated Search button.

Search button is attached code:

sir_sql = "SELECT [facturi_emise].[Numar], [Beneficiar].[NUME_BENEFICIAR], [beneficiar].[cod_beneficiar], [facturi_emise].[Data_factura], [facturi_emise].[total_plata], [facturi_emise].[data_incasare] FROM Beneficiar INNER JOIN facturi_emise ON [Beneficiar].[COD_BENEFICIAR]=[facturi_emise].[Cod_beneficiar]" If Me!numar_factura <> "" Then sir_sql = sir_sql \& "where [facturi_emise].[numar]=" \& Me!numar_factura.Value \& ";" Me!facturi_emise_cautare.Form.RecordSource $=$ sir_sql 
Me!facturi_emise_cautare.Form.Requery

GoTo sfarsit

End If

When filling following situations may occur:

- If completed Invoice_number then do not search other criteria;

- If completed dates and name of the beneficiary then will get a list of beneficiaries that were billed some products;

- If not complete beneficiary name only dates between which you want a summary of invoices then get a list of invoices issued or received between two dates.

On the right side of the bottom half of the total fields are billed and collected. These values are obtained after completion dates and Calculates pushbutton. Using this form you can get reports out on bills received or issued. To obtain such a report does billing report button.

On pressing the button in the main interface addresses beneficiaries generates a query that will result in a table with all debtor's payment of bills. After that, it will generate one Word document for each recipient individually, with the content shown in Figure 6:

By: xox Intemational
Ref: Outstanding invoices
Decar customer,
According to our accounting records, your company is registered with debts to pay invoices
issued by us. You still remember what it was about:
\begin{tabular}{|c|c|c|}
\hline Invoices Number & Invoices date & value (ron) \\
\hline 3333333 & $3 / 23 / 2013$ & 13290 \\
\hline Total & & 13290 \\
\hline
\end{tabular}
$\begin{aligned} & \text { Yours sincerely, } \\
& \text { Director SC Yyyyyy Ltd }\end{aligned}$

Figure 6. Content letter to each debtors.

Being defined by the values of status variables that characterise the system, its state at a certain moment, becomes a predictable result of the system evolution. The more the probability that the system evolves according to the trajectory for which it was designed is higher, the more the information we have about its state and subsequently, about that system is larger. In order to control the system well, it has to be well known and well organised.

In order to achieve its main goal - assistance for its decision makers in solving the management and organisational problems - a computer system can appeal to one or more information technologies. In this context, more approaches are possible:

- Utilising certain technologies independently in order to solve different aspects of a complex problem;

- Utilising some technologies that communicate with each other for transferring data and information in order to solve some problems;

- Utilising more technologies integrated in a sole system (a hybrid system).

The company considered as a dynamic system has a structure that includes the adjustment activities (feedback), leadership, production, circulation, technique and information activities. The connection of all these components can be achieved based on the information flow within the hierarchical levels of leadership. Within each subsystem, part of the dynamic system of the enterprise, the achievement of an organisation (order) strategy, which leads to obtaining an uncertainty degree of phenomena production as smaller as possible, that is to the existence of minimal entropy, is imposed. 


\section{Conclusions}

In order to improve the global performance, any company has to react to the evolution of all aspects related to computerising its own activities and be aware of their importance. The research from this paper stays within this logic and contributes to the enrichment of the information concerning the use of computer applications in the management of the outstanding invoices. The actuality and the utility of the research also result from the current concern for the analysis of the computer systems within the management activities generated by the importance that each trader has to give to this strategic resource. I consider that the proper management of the collections by tracking outstanding invoices and their impact on the organisation performances requires a transversal interdisciplinary approach, being necessary to be equally taken into account the economic, financial and information aspects.

Along with the basic software development orientated to optimising the economic activities, such applications started to be used, globally, in simulating the decisional processes, thus assuring the exertion, accompanied by computer, of the prediction attribute characteristic for the decision process.

The most significant aspect of these simulations resides in the fact that it warns the decision factor about the possible negative manifestations in the functioning of the leaded subsystem, with an acceptable time horizon before their manifestation. Thus, there is the possibility of predicting these negatives phenomena by taking the right measures in order to totally or partially eliminate them.

\section{References}

1. Velicanu M. et al., Evaluated database systems, ASE, Bucharest, 2009

2. Gherasim Z. Programming and Database, Publishing House of Tomorrow Foundation Romania, Bucharest, 2007

3. Gherasim Z. Programming and Database, Publishing House of Tomorrow Foundation Romania, Bucharest, 2007

4. Baron C., lanos-Schiller E. Management and management information systems, Pro Universitaria Publishing House, Bucharest, 2008

5. Chiru C., Constantinescu E., Jeflea V. Management Information Systems. Theory and Applications, Editura Sigma, Bucharest, 2003

6. Neacşu G., Concepts and methods used in statistics, University Publishing House, Bucharest, 2009

7. Lungu I., Bara A. Executive information systems, ASE, Bucharest, 2007

8. Ciobănică M.L. The role of organization informational system in reflecting economic performance, in Proceedings of the $15^{\text {th }}$ International Conference "The Knowledge-based Organization”, ISSN 1843-6722, "Nicolae Bălcescu” Land Forces Academy Publishing House, Sibiu, 2009, pp. 232-239. 